\title{
PENENTUAN VARIASI RASIO C/N OPTIMUM SAMPAH CAMPURAN (DEDAUNAN DAN SISA MAKANAN) TERHADAP KINERJA COMPOST SOLID PHASE MICROBIAL FUEL CELLS (CSMFC)
}

\author{
Erika Lucitawati $^{1, *}$, Arya Rezagama $^{2}$, Ganjar Samudro ${ }^{3}$ \\ ${ }^{1,2,3}$ ) Departemen Teknik Lingkungan, Fakultas Teknik, Universitas Diponegoro, Jl. Prof. \\ Soedarto, SH, Kampus Undip Tembalang, Semarang, Indonesia 50275 \\ e-mail: erika.lucitawati@gmail.com
}

\begin{abstract}
Abstrak
Rasio C/N merupakan salah satu faktor penting pada proses pengomposan dan produksi listrik dalam compost solid phase microbial fuel cells (CSMFC). Rasio C/N menggambarkan nutrisi yang tersedia bagi mikroorganisme dalam CSMFC. Besarnya nilai rasio C/N yang terdapat dalam substrat yang digunakan mempengaruhi kinerja CSMFC. Penelitian ini bertujuan untuk menentukan nilai rasio $\mathrm{C} / \mathrm{N}$ yang optimum terhadap kinerja CSMFC. Variasi nilai rasio $\mathrm{C} / \mathrm{N}$ yang digunakan yaitu 30:1, 40:1 dan 50:1. Kadar air diatur pada $60 \%$. Penelitian dilakukan secara batch selama 23 hari. Parameter yang diujikan berupa suhu, $\mathrm{pH}$, kadar $\mathrm{C}$ Organik, $\mathrm{N}$ total, $P$ total, $K$ total, rasio $C / N$, power density, dan Coulombic efficiency. Hasil penelitian menunjukkan bahwa kinerja CSMFC yang optimum terdapat dalam reaktor dengan rasio C/N 30:1 dengan nilai suhu, $\mathrm{pH}$, kadar $\mathrm{C}$ Organik, $N$ total, $P$ total, $K$ total, power density, dan Coulombic efficiency secara berturut-turut sebesar $7,1,27,5^{\circ} \mathrm{C}, 20,31 \%, 1,63 \%, 0,19 \%, 0,21 \%, 12,47$, $48,02 \mathrm{~mW} / \mathrm{m}^{2}$ dan $0,19 \%$.
\end{abstract}

Kata kunci: rasio C/N, kinerja CSMFC

\begin{abstract}
$\mathrm{C} / \mathrm{N}$ ratio is one of important factors which affects composting and power generation in compost solid phase microbial fuel cells (CSMFC). C/N ratio describes available nutritions for microorganisms in CSMFC. C/N ratio values in substrate which is used influences performance of CSMFC. Aim of this study is to determine optimum C/N ratio value in CSMFC. This study uses variation of $C / N$ ratio of 30:1, 40:1, and 50:1. This study is carried aout in batch for 23 days. Parameters which are used in this study are temperature, $p H$, organic $C$, total $N$, total $P$, total $K, \mathrm{C} / \mathrm{N}$ ratio, power density, and Coulombic efficiency. Result of this study shows that optimum CSMFC performance is in reactor with $\mathrm{C} / \mathrm{N}$ ratio 30:1 and temperature, $\mathrm{pH}$, organic $\mathrm{C}$, total $N$, total $P$, total $K$, power density, and Coulombic efficiency values are $7,1,27,5{ }^{\circ} \mathrm{C}$, $20,31 \%, 1,63 \%, 0,19 \%, 0,21 \%, 12,47,48,02 \mathrm{~mW} / \mathrm{m}^{2}$ dan $0,19 \%$ respectively.
\end{abstract}

Keywords: C/N ratio, CSMFC performance

\section{Pendahuluan}

Compost solid phase microbial fuel cells (CSMFC) merupakan salah satu alternatif teknologi pengolahan sampah organik yang dapat menghasilkan energi ramah lingkungan. Pengomposan merupakan cara pengolahan sampah organik yang sering diterapkan di masyarakat, namun hasil samping pengomposan, yaitu gas metan dan karbon dioksida, akan dilepaskan dalam jumlah tertentu bergantung jenis pengomposan yang dilakukan. Seperti yang diketahui, gas tersebut termasuk ke dalam gas rumah kaca 
yang dapat merusak lapisan ozon. Selain itu, pengomposan membutuhkan waktu tinggal yang lama dan nilai produk yang rendah. Reimers et al. (2001) memperkenalkan konsep Solid Phase Microbial Fuel Cell (SMFC) yang memanfaatkan bakteri untuk memetabolisme akumulasi residu organik, sehingga menghasilkan daya listrik yang berkelanjutan. SMFC menjadi teknologi yang mengadopsi mekanisme fermentasi tanah kompos untuk menghasilkan listrik dari daur ulang sampah organik. Bakteri digunakan dalam proses pada SMFC ini dan berperan sebagai biokatalis untuk mengoksidasi senyawa organik yang tersedia sehingga dapat menghasilkan listrik (Wang, et al., 2013).

CSMFC memanfaatkan bakteri dalam mengolah residu organik serta menghasilkan potensi listrik yang berkelanjutan. Keunggulan CSMFC ini adalah tingginya reduksi bahan organik, dihasilkannya lumpur yang lebih sedikit dan dapat diproses lebih lanjut menjadi kompos, dihasilkannya pupuk cair, dihasilkannya biogas, dan dihasilkannya energi listrik secara langsung. Telah banyak penelitian MFC dengan menggunakan berbagai macam sampah padat organik agar dapat menghasilkan energi listrik. Penelitian dengan menggunakan kombinasi substrat berupa limbah kacang-kacangan, kopi, dan sekam padi menunjukkan bahwa kadar air sebesar $60 \%$ dapat menghasilkan power density sebesar 4,6 $\mathrm{mW} / \mathrm{m}^{2}$ (Wang, et al., 2015). Produksi listrik yang dihasilkan pada SMFC dengan substrat berupa sampah campuran kantin-daun yaitu sebesar 43,8 $\mathrm{mW} / \mathrm{m}^{2}$ dengan penurunan konsentrasi COD sebesar 90 \% (Muthi'ah, 2017).
Penelitian ini memiliki tujuan untuk mengetahui kinerja CSMFC dalam produksi kompos dan listrik dengan parameter tegangan, arus, hambatan, $\mathrm{pH}$ dan suhu apabila menggunakan sumber sampah organik padat berupa sampah dedaunan dan sisa makanan dengan varisiasi kadar air sebesar $40 \%$ dan $60 \%$ serta variasi rasio $\mathrm{C} / \mathrm{N}$ sebesar 30:1, 40:1, dan 50:1.

\section{Metodologi Penelitian}

Penelitian dilakukan dengan menggunakan 4 reaktor single chamber yang terdiri atas 3 unit reaktor variasi dan 1 unit reaktor kontrol. Penelitian dilakukan dengan metode dekstruktif di mana reaktor digunakan sekali pada tiap pengukuran sampel. Pengambilan sampel dilakukan pada $\mathrm{H}_{0}, \mathrm{H}_{1}$, $\mathrm{H}_{3}, \mathrm{H}_{5}, \mathrm{H}_{10}, \mathrm{H}_{15}, \mathrm{H}_{20}$ dan $\mathrm{H}_{23}$. Pada $\mathrm{H}_{0}$, dilakukan pengambilan sampel sebelum dimasukkan ke dalam reaktor. Dengan demikian, reaktor yang dibutuhkan sebanyak 21 reaktor. Penelitian dilakukan dengan variabel bebas berupa rasio $\mathrm{C} / \mathrm{N}$, variabel terikat berupa parameter kualitas kompos (suhu, $\mathrm{pH}$, kadar $\mathrm{C}$ organik, $\mathrm{N}$ total, rasio $\mathrm{C} / \mathrm{N}$, $\mathrm{P}$ total, dan $\mathrm{K}$ total) dan produksi listrik (power density, Coulombic efficiency), serta variabel kontrol berupa kadar air, volume substrat dan penambahan aktivator. Campuran sampah dimasukkan ke dalam reaktor hingga mencapai volume 2/3 reaktor (Samudro, et al., 2017).

\section{Hasil dan Pembahasan}

\section{Produksi Kompos}

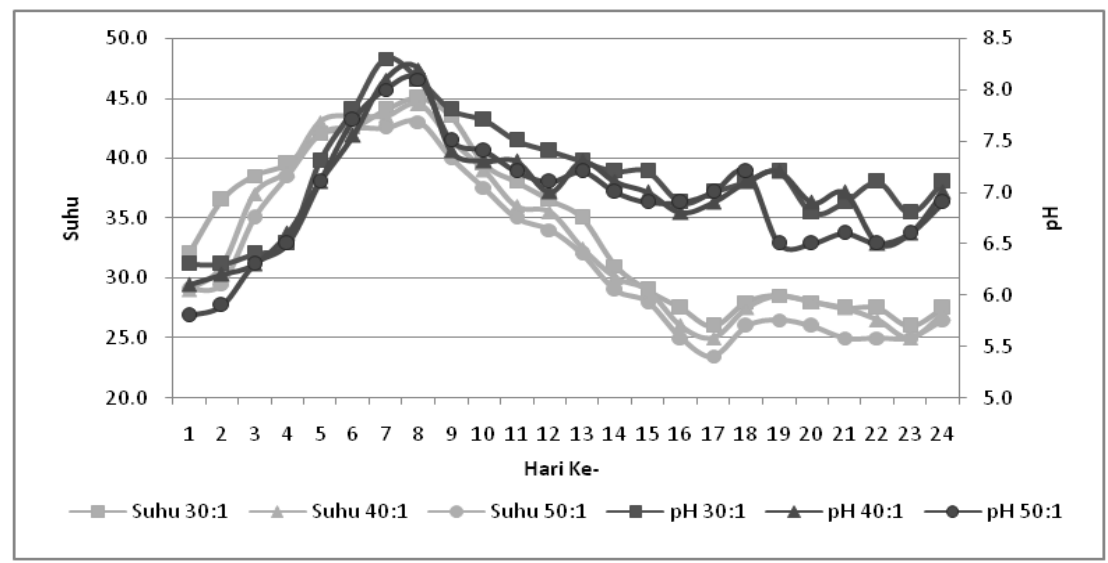

Gambar 1. Grafik Perubahan Suhu dan pH dalam Pengomposan

Berdasarkan Gambar 1, suhu dan $\mathrm{pH}$ pada proses pengomposan mengalami peningkatan sampai hari ke- 7 akibat peningkatan aktivitas mikroorganisme dalam menguraikan bahan organik. Suhu pengomposan tertinggi terjadi dalam rasio $\mathrm{C} / \mathrm{N}$ 30:1 sebesar $45^{\circ} \mathrm{C}$ dan terendah pada 50:1 sebesar $43{ }^{\circ} \mathrm{C}$. Setelah terjadi peningkatan, suhu kembali menurun dan stabil sampai hari ke- 23. Penurunan suhu ini 
terjadi akibat nutrisi untuk mikrorganisme mulai berkurang. Sedangkan, peningkatan nilai $\mathrm{pH}$ terjadi akibat adanya produksi ammonia dalam ammonifikasi dan mineralisasi nitrogen organik karena aktivitas mikroorganisme (Huang, et al., 2004). Setelah terjadi peningkatan, nilai $\mathrm{pH}$ kembali menurun secara bertahap dan mencapai nilai yang mendekati netral pada akhir pengomposan.
Penurunan yang terjadi disebabkan oleh volatilisasi nitrogen ammonia dan pelepasan ion $\mathrm{H}^{+}$akibat proses nitrifikasi oleh bakteri nitrifikasi (Huang, et al., 2004).Penelitian ini sejalan dengan Kamolmanit \& Reungsang (2006) serta Ismayana, et al. (2014) yang menunukkan bahawa rasio C/N 30:1 akan menghasilkan suhu pengomposan yang optimum.

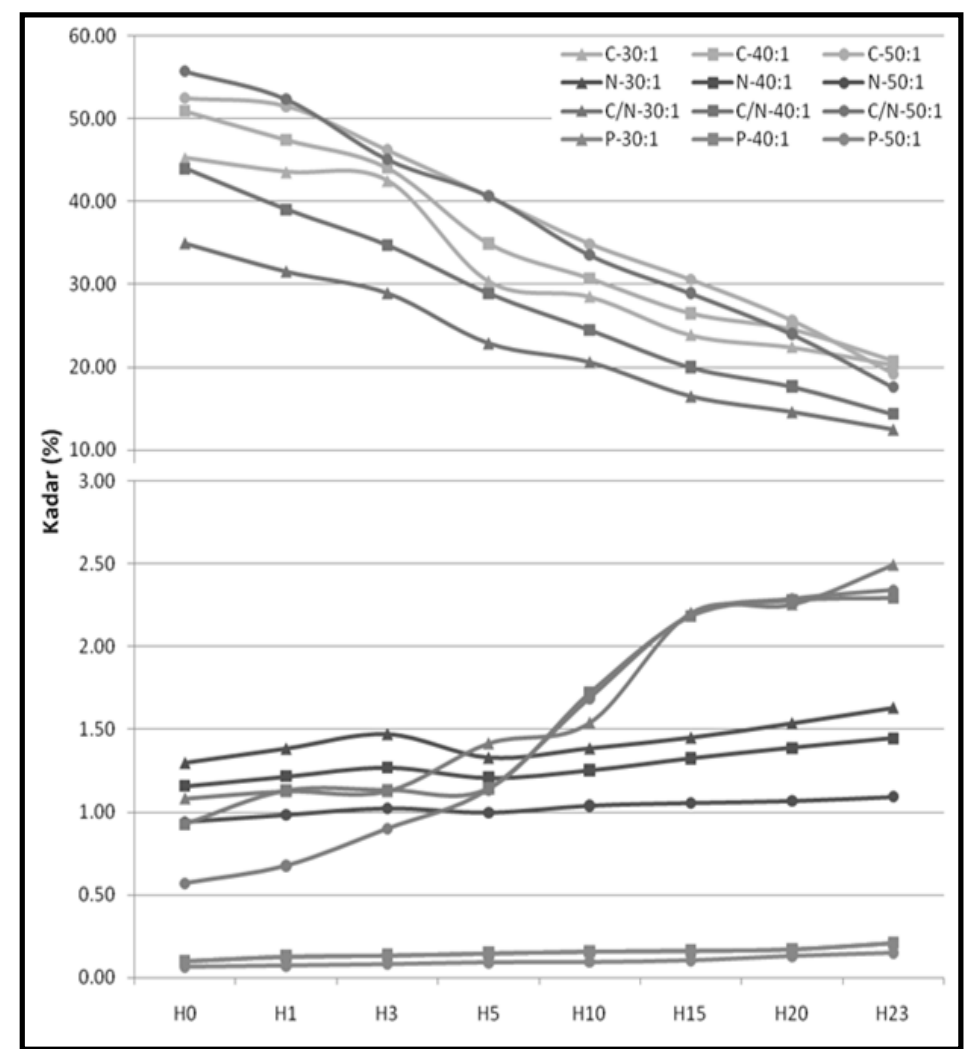

Gambar 2. Grafik Perubahan Kadar C Organik, N Total, P Total, K Total, dan Rasio C/N dalam Pengomposan

Berdasarkan Gambar 2, kandungan unsur-unsur hara mengalami perubahan selama pengomposan. Kandungan $\mathrm{C}$ organik dan rasio $\mathrm{C} / \mathrm{N}$ mengalami penurunan akibat bahan organik yang ada dalam substrat digunakan oleh mikroorganisme sebagai sumber energi dan dioksidasi menjadi $\mathrm{CO}_{2}$ (Bernal, et. al., 2009; Azim et al., 2014). Ketersediaan karbon dalam proses dekomposisi sangat dibutuhkan sebagai penyedia energi untuk mikroorganisme agar bekerja secara optimal (Mehl, 2008). Kandungan $\mathrm{N}$ total, $\mathrm{P}$ total, dan $\mathrm{K}$ total pada seluruh reaktor mengalami peningkatan selama pengomposan. Akan tetapi, pada kandungan $\mathrm{N}$ total mengalami penurunan pada hari ke-5 akibat volatilisasi $N$ sebagai $\mathrm{NH}_{3}$ karena meningkatnya $\mathrm{pH}$ pengomposan (Spencer \& Heyst, 2013). Mikroorganisme membutuhkan nitrogen dalam pembentukan protein (Kumar, et. al., 2015). Kandungan $\mathrm{P}$ total dan $\mathrm{K}$ total seluruh reaktor meningkat hingga akhir pengomposan karena dekomposisi bahan organik dan kehilangan masa selama pengomposan (Lü, et al., 2013). Selain itu, peningkatan $\mathrm{P}$ dan $\mathrm{K}$ yang terjadi akibat adanya kehilangan $\mathrm{C}$ organik, $\mathrm{H}, \mathrm{O}$, dan $\mathrm{N}$ membentuk $\mathrm{CO}_{2}$ dan $\mathrm{H}_{2} \mathrm{O}$ (Larney, et al., 2006; Kamolmanit \& Reungsang, 2006). Fosfor merupakan salah satu unsur yang penting dalam metabolisme organisme karena terdapat di dalam asam nukleat, yaitu fosfolipid yang membentuk membran selular, molekul ATP dan ADP serta senyawa intermediet dalam respirasi dan fotosintesis (Fuentes, et al., 2006). Secara keseluruhan, hasil pengomposan seluruh variasi rasio $\mathrm{C} / \mathrm{N}$ telah memenuhi persyaratan dalam SNI 197030-2004. Rasio C/N 30:1 memiliki waktu pada pengomposan yang lebih cepat. Pada hari ke-15, reaktor dengan rasio $\mathrm{C} / \mathrm{N}$ 30:1 telah memenuhi persyaratan yang terdapat dalam SNI 19-7030-2004. Hal ini sejalan dengan penelitian yang dilakukan oleh Wang et al. (2015) dengan nilai rasio $\mathrm{C} / \mathrm{N}$ mendekati 30:1 (31,4:1) menghasilkan pengomposan yang lebih optimum dengan suhu yang lebih tinggi. 


\section{Produksi Listrik}

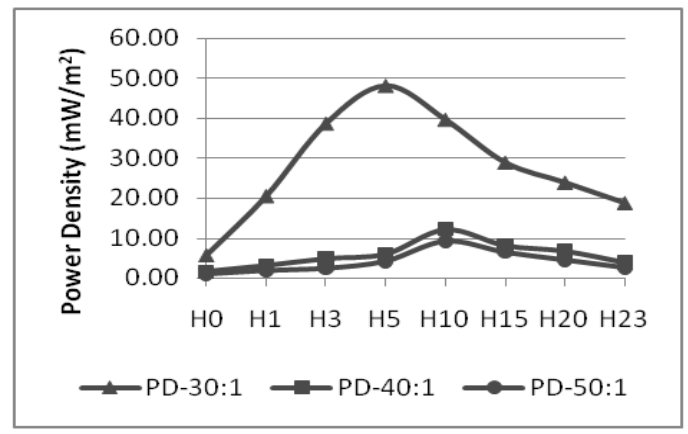

(a)

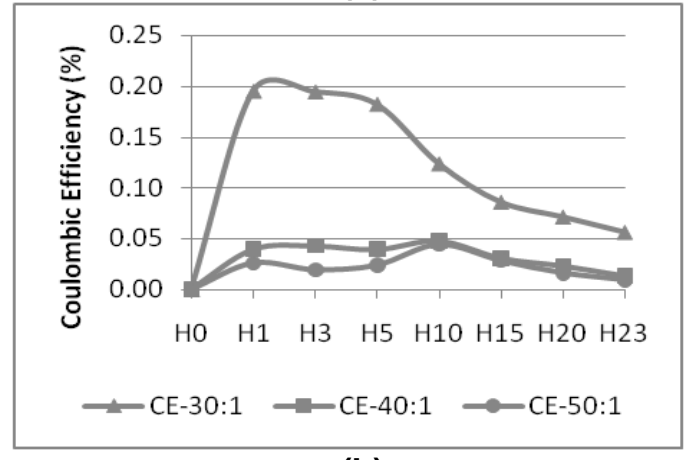

(b)

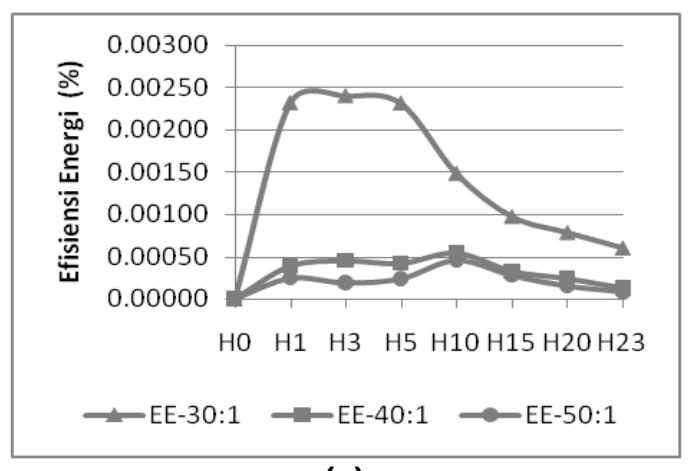

(c)

Gambar 3. Produksi Listrik dalam CSMFC (a) Power Density (b) Coulombic Efficiency (c) Efisiensi Energi

Berdasarkan Gambar 3, dapat dilihat bahwa nilai power density, Coulombic efficiency, dan efisiensi energi pada setiap reaktor CSMFC mengalami peningkatan pada tahap awal pengoperasian. Nilai power density tertinggi terdapat pada rasio $\mathrm{C} / \mathrm{N} 30: 1$ sebesar $48,02 \mathrm{~mW} / \mathrm{m}^{2}$ dan terendah pada $50: 1$ sebesar $6,40 \mathrm{~mW} / \mathrm{m}^{2}$. Produksi daya perlu dinormalisasi agar menggambarkan produksi daya oleh sistem secara spesifik (Logan, 2008). Nilai Coulombic efficiency tertinggi terdapat pada reaktor 30:1 sebesar $0,19 \%$ dan terendah pada 50:1 sebesar $0,04 \%$. Setelah mencapai nilai maksimum, nilai Coulombic efficiency menurun hingga akhir proses karena pemanfaatan akseptor elektron alternatif oleh bakteri dan proses kompetitif dan pertumbuhan mikroorganisme. Couloumbic efficiency merupakan banyaknya elektron yang tersimpan dalam biomasa yang kemungkinan dapat dipanen sebagai arus listrik dalam sistem. Nilai efisiensi energi tertinggi yang diperoleh pada reaktor 30:1 sebesar $0,00240 \%$ dan terendah pada 50:1 Sebesar $0,00046 \%$. Efisiensi energi merupakan faktor yang perlu diperhatikan dalam mengevaluasi kinerja sebuah MFC dalam memproduksi listrik (Logan et al., 2006). Nilai yang diperoleh tersebut menunjukkan bahwa rasio $\mathrm{C} / \mathrm{N}$ yang lebih tinggi memiliki nilai efisiensi energi yang lebih rendah. Fenomena ini menggambarkan bahwa peningkatan produksi listrik tidak sebanding dengan peningkatan konsentrasi awal substrat. Kompetisi antar komunitas mikroba dalam sistem yang semakin meningkat dapat menghasilkan beragam aktivitas metabolik yang mengurangi densitas daya listrik keluaran (Utami, et al., 2017).

Reaktor dengan rasio $\mathrm{C} / \mathrm{N} \quad 30: 1$ menghasilkan power density yang lebih tinggi. $\mathrm{Hal}$ ini sejalan dengan penelitian Wang et al. (2015) yang menunjukkan (błhwa rasio $\mathrm{C} / \mathrm{N}$ 31,4:1 menghasilkan power density yang optimum sebesar $1,278 \mathrm{~mW} / \mathrm{m}^{2}$ karena rasio $\mathrm{C} / \mathrm{N}$ 30:1 merupakan nilai yang optimal dalam pengomposan dan mempengaruhi kinerja daya optimum dalam SMFC. Nilai Coulombic efficiency yang dihasilkan oleh reaktor CSMFC tergolong lebih rendah dibandingan dengan penelitian yang dilakukan oleh Liu et al. (2004) yang menghasilkan nilai Coulombic efficiency sebesar $3-12 \%$ dengam substrat air limbah. Hal ini terjadi karena adanya akseptor elektron lain (sulfat dan nitrat) dan difusi oksigen dari kompartemen katoda menuju anoda (Lu, et al., 2009). Nilai efisiensi energi yang diperoleh sejalan dengan penelitian Utami et al. (2017) dengan menggunakan substrat glukosa pada MFC akan menghasilkan efisiensi energi dengan nilai maksimum sebesar $0,000179 \%$.

\section{Kesimpulan}

Berdasarkan analisis yang telah dilakukan, rasio $\mathrm{C} / \mathrm{N}$ yang semakin rendah akan mempercepat proses pengomposan. Variasi rasio $\mathrm{C} / \mathrm{N}$ 30:1 merupakan variasi optimum dalam pengomposan dan produksi listrik berdasarkan analisis skoring. Hasil yang diperoleh yaitu kadar C organik sebesar 20,31 , kadar $\mathrm{N}$ total sebesar 1,63\%, kadar $\mathrm{P}$ total sebesar $0,21 \%$, kadar $\mathrm{K}$ total sebesar 2,49, rasio $\mathrm{C} / \mathrm{N}$ sebesar $12,47, \mathrm{pH}$ sebesar 7,1 dan suhu $27,5^{\circ} \mathrm{C}$, serta menghasilkan 
power density sebesar 48,02 $\mathrm{mW} / \mathrm{m}^{2}$, Couloumbic efficiency sebesar 0,19\%.

Ucapan Terima Kasih: Ucapan terima kasih disampaikan kepada Bapak Ganjar Samudro yang telah mendanai dan Bapak Arya Rezagama yang telah membimbing dalam penelitian ini.

\section{Daftar Pustaka}

Azim, K., Ouyahia, K., Amellouk, A., Perissol, A., Thami Alami, I., \& Soudi, B. (2014). Dynamic Composting Optimization Through CN Ratio Variation as A Startup Parameter. In ISOFAR Scientific Conference (pp. 787-790). Istanbul: Organic World Congress.

Bernal, M. P., Alburquerque, J. A., \& Moral, R. (2009). Composting of Animal Manures And Chemical Criteria For Compost Maturity Assessment. A Review. Bioresource Technology, 100(22), 54445453.

http://doi.org/10.1016/j.biortech.2008.11. 027

Fuentes, B., Bolan, N., Naidu, R., \& Mora, M. D. L. L. (2006). Phosphorus in Organic Waste-Soil Systems. Revista de La Ciencia Del Suelo Y Nutrición Vegetal, $6(2)$, http://doi.org/10.4067/S071827912006000200006

Huang, G. F., Wong, J. W. C., Wu, Q. T., \& Nagar, B. B. (2004). Effect of $\mathrm{C} / \mathrm{N}$ on Composting of Pig Manure With Sawdust. Waste Management, 24(8), 805-813.

http://doi.org/10.1016/j.wasman.2004.03. 011

Ismayana, A., Indrasti, N. S., \& Erica, N. (2014). Pengaruh Rasio C / N Awal Dan Laju Aerasi Pada Proses CoComposting Blotong dan Abu Ketel. Jurnal Bumi Lestari, 14(1), 39-45.

Kamolmanit, N., \& Reungsang, A. (2006). Effect of Carbon To Nitrogen Ratio on the Composting of Cassava Pulp With Swine Manure. Journal of Water and Environment Technology, 4(1), 18. Retrieved from https://www.jstage.jst.go.jp/article/jwet/4/ 1/4_1_33/_pdf

Kumar, S., \& Kumar, S. (2015). Composting of Municipal Solid Waste. Environmental Science, Toxicology and Food Technology, 8551, 20-29. http://doi.org/10.3109/07388551.2010.49 2207

Larney, F. J., Sullivan, D. M., Buckley, K. E., \& Eghball, B. (2006). The Role of
Composting In Recycling Manure Nutrients. Canadian Journal of Soil Science, $\quad 86(4)$, 597-611. http://doi.org/10.4141/S05-116

Liu, H., Liu, H., Ramnarayanan, R., Ramnarayanan, R., Logan, B. E., \& Logan, B. E. (2004). Production Of Electricity During Wastewater Treatment Using A Single Chamber Microbial Fuel Cell. Environmental Science \& Technology, 38(7), 2281-5. http://doi.org/10.1021/es034923g

Logan, B. E. (2008). Power Generation. In Microbial Fuel Cells (pp. 44-60). New Jersey: John Wiley \& Sons, Inc. All. http://doi.org/10.1002/9780470258590.c h4

Logan, B. E., Hamelers, B., Rozendal, R., Schroder, U., Keller, J., Fraguia, S., ... Rabaey, K. (2006). Critical Review Microbial Fuel Cells: Methodology and Technology. Environmental Science \& Technology, 40(17), 5181-5192. http://doi.org/10.1021/es0605016

Lü, D. an, Yan, B. xing, Wang, L. xia, Deng, Z. qiang, \& Zhang, Y. bin. (2013). Changes In Phosphorus Fractions And Nitrogen Forms During Composting Of Pig Manure With Rice Straw. Journal of Integrative Agriculture, 12(10), 1855$1864 . \quad$ http://doi.org/10.1016/S20953119(13)60400-1

Lu, N., Zhou, S. gui, Zhuang, L., Zhang, J. tao, \& Ni, J. ren. (2009). Electricity Generation From Starch Processing Wastewater Using Microbial Fuel Cell Technology. Biochemical Engineering Journal, 43(3), 246-251. http://doi.org/10.1016/j.bej.2008.10.005

Muthi'ah, H. (2017). Pengaruh Variasi Volume Sampah Padat Organik dan Sumber Bakteri Terhadap Kinera Solid Phase Microbial Fuel Cell (SMFC). Semarang.

Samudro, G., Nugraha, W. D., \& Priyambada, I. B. (2017). Kajian Pemilihan Sumber Mikroorganisme Solid Phase Microbial Fuel Cell (SMFC) Berdasarkan Jenis Dan Volume Sampah, Power Density Dan Efisiensi Penurunan COD. Sains Dan Teknologi Lingkungan, 9, 114-121.

Spencer, J. L., \& Van Heyst, B. J. (2013). Effect Of Different Intermediate Amendments $\mathrm{On} \mathrm{Ph}$ And Ammonia Emissions Of Composted Poultry Mortalities. Journal of Applied Poultry Research, 22(4), 700-714. http://doi.org/10.3382/japr.2012-00632

Utami, T. S., Arbianti, R., \& Mulyana, G. M. (2017). Evaluasi Produksi Listrik Sumber Energi Terbarukan Sel Elektrokimia Berbasis Mikroba Pada Volume Reaktor 
Yang Berbeda. Seminar Nasional Sains Dan Teknologi 2017, (November), 1-8.

Wang, C. T., Lee, Y. C., \& Liao, F. Y. (2015). Effect of Composting Parameters on The Power Performance of Solid Microbial Fuel Cells. Sustainability (Switzerland), $7(9)$, 12634-12643. http://doi.org/10.3390/su70912634
Wang, C. T., Liao, F. Y., \& Liu, K. S. (2013). Electrical Analysis of Compost Solid Phase Microbial Fuel Cell. International Journal of Hydrogen Energy, 38(25), 11124-11130. http://doi.org/10.1016/j.ijhydene.2013.02. 120 